\title{
Analysing from a systematic perspective the Albanian nationalism in the Ottoman Empire
}

\section{SEÇKIN ARPALIER - IRIEDA HAMZAJ}

The Balkan Peninsula was under the rule of the Ottoman Empire for six centuries. This long Ottoman presence and co-existence directly influenced the Balkan peoples in several respects: politics, military, religion, economy, culture, social, demography, art, architecture, state tradition, state institutions and so on. Considering the multiethnic and multireligious structure of the region, the Ottoman Empire was forced to use various regulatory means to have a peaceful and prosperous region. Thus, the Ottoman Empire implemented systems and policies in the Balkans such as "İstimâlet" (tolerance and protection), "Millet", "Devshirmeh", "Jizya", "Çift-Hane”, "Timar", "Vilayet", "İkan”. The effect of these policies on the population of the region has been examined on a systematical basis. These types of policies also had an impact on the subsequent development of nationalism in the Balkans. Nationalism in the Balkans began in the early 19 th century with the Greek and Serbian uprisings; these uprisings were largely armed, and later spread to other Balkan peoples. In all these developments, Albanian nationalism makes a difference. It is a fact that the rule of the Ottoman Empire has shaped the Albanian nationalism as it has done with all Balkan nationalism. However, the Albanian nationalism was developed under the conditions that the Ottoman Empire established in the region, videlicet on the policies it applied. The nature of the Albanian nationalism differs from the other regional ones in that it is not an aggressive movement and that it developed more on the basis of a cultural awakening. The investigation of the steps that resulted in this variation holds a particular significance For a real understanding of all the mentioned changes one has to know the systems and policies that are to be explained in this study.

Keywords: Ottoman Empire, Albanians, Nationalism, Administrative System, Balkans

\section{Az Oszmán Birodalom albán nacionalizmusa rendszerszintü perspektívából elemezve}

A Balkán-félsziget hat évszázadon keresztül az Oszmán Birodalom uralma alatt állt. Ez a hosszú közös múlt az Oszmán Birodalom politikai, katonai, vallási, közgazdasági, kulturális, társadalmi, demográfiai, müvészeti, épitészeti, valamint állami hagyományai és rendszere terén is (és még sok más 
módon is) kifejtette hatását. A terület kevert etnikai és vallásos összetétele miatt az Oszmán Birodalom a béke és a jólét érdekében számos különböző szabályozóeszközhöz folyamodott. Az Oszmán Birodalom olyan irányelveket is beiktatott a balkán területén, mint a: "İstimâlet" (tolerancia és védelem), "Millet", "Devshirmeh", "Cizye", "Çift-Hane", "Timar", "Vilayet", "İskan". A dolgozat szisztematikusan vizsgálja ezek hatását a terület lakosságára. Ezek az irányelvek hatással voltak a török uralmat követöen a Balkánon kialakuló nacionalizmusra is. Ez a 19. század elején a görög és szerb lázadásokkal kezdődött (ezek jellemzöen fegyveres lázadások voltak), majd átterjedt a környezö Balkán nemzetekre is. Ezek közül az albán mozgalom volt az, ami jelentös változást hozott. Igaz ugyan, hogy a török birodalom más balkáni nemzetek nacionalizmusára is hatással volt, de az albán nacionalizmus még a török által felállított helyzet alatt fejlödött ki. Az albán nacionalizmus abban különbözik az azt körülvevö államokétól, hogy nem agresszióra alapozza mozgalmát, hanem kulturális és társadalmi ébredéssel éri el célját. Ezek vizsgálata azért fontos, mert ez határozza meg a dolgozatban kifejtett rendszerek és irányelvek mögöttes okait.

Kulcsszavak: Oszmán Birodalom, albánok, nacionalizmus, adminisztrációs rendszer, Balkán

\section{Introduction}

Besides the advance of the Ottoman Empire to Rumelia, with the death of Stefan Dušan, the Serbian Kingdom was weakened and divided. Thus, the Oghuz Turks ${ }^{1}$ got involved in the Balkans in 1371 with the Battle of Chernomen. With the absence of political authority in the region, day by day the influence of the Ottoman Empire in the Balkans increased. The dominance of the Ottoman Empire in the Balkans, which lasted until the beginning of the 20th century, began on 28 June 1389 with the Battle of Kosovo on the Kosovo Field (Fusha e Kosovës). The victory of the Ottoman army led by Murad I against the army led by the Serbian commander Lazar Hrebeljanović, consisting of Serbian, Bosnian, Croatian, Albanian, Hungarian, Bulgarian and Czech soldiers, was accepted as one of the biggest turning points of the history of the Balkans, including Turkish, Albanian and Serbian history.

The domination ${ }^{2}$ of the Ottoman Empire over the Balkans from the 14th until the early 20th centuries had a direct impact on the region in many ways, including political,

1 The Huns (a Turkish people in antiquity) temporarily entered the Balkans under the leadership of Atilla, ruler of the Hun Empire. From the Late Middle Ages, the Ottoman Turks dominated the region, who had, besides their Turkish identity, an Islamic identity as well.

2 Pax Ottomana, Latin for "Ottoman Peace". It refers to the term used to describe the sovereignty, stability and order that existed in the territories of the Ottoman Empire (Balkans, Anatolia, Middle East, Caucasus, North Africa) compared to other parts of the world. For details: GöYÜNÇ 2001, 31-49. 
military, religious, economic, cultural, social, demographic, artistic, architectural, state tradition and state institutions. Depending on the region, the Balkan languages have taken from Turkish between 2000-5000 words. Moreover, the Ottoman heritage stands out in their impact on clothing, eating, drinking, folk music and behavior. ${ }^{3}$ The Ottoman administration, as it affected the whole Balkans, directly affected the Albanian nationalism as well. Even in the words of Maria Todorova, "today's Balkans are the Ottoman heritage".

While the Albanian nationalist movement is the latest nationalist movement in the Balkans, it has developed differently compared to other Balkan nationalisms. This change is considered as one of the most remarkable events of the history of the Balkans in the 19th century. The reason why Albanian nationalism is the latest nationalist movement that awoke in Europe is linked with the system and policy during the reign of the Ottoman Empire.

The policy of "istimâlet" (tolerance and protection) which was implemented by the Ottoman Empire on the conquered territories in the Balkans is one of the most important elements of the empire's attachment to the region. According to Maria Todorova, the Ottoman Empire, which did not separate the non-Muslims from the Muslim population, with certain privileges, protected their right to live, to have a property and the freedom of worship, thus was rapidly spreading and consolidated a solid social structure in the region. ${ }^{5}$

\section{The Social Structure in the Ottoman Empire}

Two different social structures were found in the Ottoman Empire. The first group is the "military" (askerî) group that governs, comprising the sultan, his family, rulers and relatives. Soldiers, religious officials, court officials and bureaucrats that belong to the group are excluded from the tax liability. Since the aim of the establishment of the Ottoman Empire was to spread Islam through its conquests, and due to the fact that the rulers were more interested in military duties, naming the ruling class as military was a decisive factor. Apart from the ruling group, there is a class known as "reâyâ", 6 comprising the rest of the society which were under the rule of the sovereign.

Without making any distinction between the Muslim and non-Muslim, all the rest of the population - that were not comprised in the ruling group - formed the rest of

3 İNALCIK 2011, 18.

4 Todorova 2010, 36.

5 TODOROVA 2010, 16.

6 According to the Turkish dictionary explanation, the term "sürü" in international literature is explained as "the flock". AKşıN 2007, 8-9. https://books.google.com.tr/books?id=rt4TCgAAQ-

BAJ\&pg $=$ PA11\&lpg $=$ PA11\&dq $=$ reaya + the + flock \&source $=$ bl\&ots $=$ N6DiIPLFVK\&sig $=$ ntciDNSgf3Ind9ON9T6uGaB9VKQ\&hl=tr\&sa $=$ X\&ved=0ahUKEwiTiomb78fWAhWla5oKHXJEBA8Q6AEIOzAD\# $\mathrm{v}=$ onepage\& $\mathrm{q}=$ reaya $\& \mathrm{f}=$ false $(06.10 .2019)$. 
the "tebaa" (society). ${ }^{7}$ Reâyâ class included not only the peasants engaged in agriculture and animal husbandry, but also merchants, artisans and nomadic communities in the city and town were part of this class. Unlike the military (askerî) class, the reâyâ class had tax obligations. Contrary to popular belief, there was a system where the transition between classes is possible. Both the person in the reâya class could be included in the ruling class and the "sipahi" ${ }^{8}$ who did not participate in the campaigns could pass to the reâyâ class. ${ }^{9}$

It is seen that many Albanians have risen to bureaucratic services, palace duties, and vizier office. The Albanian presence in the Ottoman ruling section, which did not experience a frozen social stratification, also directly influenced Albanian nationalism. The fact that many of the leaders ${ }^{10}$ of Albanian nationalism served the Ottoman bureaucracy distinguishes Albanian nationalism from other Balkan nationalisms. Yet for other Balkan nationalisms, the only objective was independence. However, until the last moment, many Albanians wanted their autonomous existence to be under the protection of the Ottoman Empire since the Ottomans presented theirselves as protectors of Albanian lands against the danger coming from the Slavic and Greek expansionist politics. ${ }^{11}$ Moreover, the administration had favoured the Albanians in many ways during centuries, while in the latest years of the empire, the protection of the Yıldız and Çırağan Palaces by the Albanians during the reign of Abdulhamid II (which protection showed his confidence in Albanians) was the reason of developing a vaster policy of tolerance towards them. Abdulhamid II's usage of Albanian words in some of his speeches is another indication of positive relations between the administration and Albanians. ${ }^{12}$

7 ESER 2010, 208. This Journal can be reached through the following link: http://sbe.balikesir.edu.tr/ dergi/edergi/c13s24/makale/c13s24mk.pdf (06. 10. 2019)

8 Spahi (Sipahi) was a social class that formed the cavalry of the Ottomans within Janissaires. It was divided into two main groups; the provincial "Tımarlı Sipahi" and the troops of the palace "Kapıkulu Sipahi." "Spahi” www.collinsdictionary.com/dictionary/english/spahi (06. 10. 2019).

9 "Reaya sınıfına genel bir bakış" www.tarihhaber.net/reaya-sinifina-genel-bir-bakis/ (06. 10. 2019).

10 Some of the leaders of Albanian nationalism like; Vassa Efendi (Vaso Pashë Shkodrani), Şemseddin Sami (Sami Frashëri), Fraşırili Abdul Bey (Abdyl Frashëri), Naim Frashıri (Naim Frashëri), İsmail Kemal Bey (İsmail Qemali), İsmail Kemal Bey (İsmail Qemali), Hasan Prishtina - Hasan Berisha) performed important tasks in Ottoman bureaucracy.

11 FISCHER 2014, 30-31.

12 FISCHER 2014, 30-31. 


\section{Millet System}

Since the foundation of the Ottoman Empire, Muslim and non-Muslim peoples have been living all together. The legal basis of the relationship between non-Muslim "reâyâ" and the state was realised only with the laws published during Sultan Mehmed the Conqueror's reign. By granting some administrative, judicial and legal rights first to the Greek "reâyâs" and then to the "Zimmis"13 of Galata, Sultan Mehmed the Conqueror laid the foundations of the "Millet System". The concept of "Millet"14 is defined in Şemseddin Sami's ${ }^{15}$ "Kamus-i Türk-i" dictionary as "religion, sect, the name given to the community belonging to a religion or sect". ${ }^{16}$

The "Millet System", which laid its foundations during the reign of Sultan Mehmed the Conqueror, was officially recorded in Ottoman documents for the first time in an edict (ferman) of 1517 during the reign of Sultan Selim I. The usage of this concept continued until the Ottoman Reform Edict (Islahat Ferman) of 1856, then the term "Cemaat" (Community) was used instead of "Millet". The Millet System, which directly affected the nationalism in the Balkans, provides - under Islamic law of the state - all freedom of religion, and worship were guaranteed under the satus of "zimmî" to all non-Muslims who were people of the book (Ahl al-Kitāb), ${ }^{17}$ moreover their safety of life and property was also guaranteed.

The notion of Millet in the Ottoman Empire, which embodies the religious belonging, is an entirely diverse notion from the notion and the perception of the minority status that we have nowadays. The persons who live within the Millet they belong to, were under the spiritual, financial and also administrative authority of that community. No religious community was pressed in matters of belief, moreover, they were also allowed to build and restore their places of worship, establish foundations and retain ownership of these foundations. ${ }^{18}$

13 Zimmî was the name given to the non-Muslim community, it included the people that were part of Ahl Ahl al-Kitāb (People of the Book). This part of the population paid tributes to the Islamic State. It is the simplified version of the word "dhimmï" in Arabic. "Zimmî", https://islamansiklopedisi.org. tr/zimmi (07. 10. 2019)

14 The concept of "Millet" in the modern Turkish language signifies "nation".

15 Şemseddin Sami (Sami Frashëri), who is a linguist, writer, poet, and historian, is considered to be a very important intellectual in both societies in terms of his contributions to Turkish and Albanian language. He is regarded both as one of the leaders of Albanian nationalism and as a representative of Turkish nationalism and Ottomanism through the contributions of his work.

16 “Millet Nedir?", www.yucedevlet.com/millet-nedir.html (07. 10. 2019).

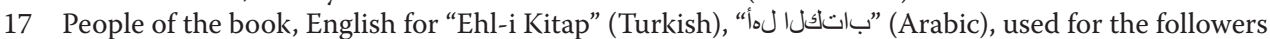
of the monotheistic religion who believe in the holy books mentioned in Quran like Bible, Torah and Zabur (Psalm), etc. "Ahl al-Kitāb", www.britannica.com/topic/Ahl-al-Kitab (07. 10. 2019)

18 Konan 2011, 269-270. 
Family and social issues such as marriage, divorce, and inheritance were resolved within the Millet. The person who was deemed to be the interlocutor of the Sultan in matters related to the people was called "milletbaşı". In order to carry out this task, "milletbaşı" was also supported by the empire. Unlike the conflicts and assimilation attempts of minorities in the modern world, the Millet System allowed them to live safely within their own social group. The situation of the nations included in the Millet System cannot be compared with the situation of minority communities living in colonialist empires or with those of federative structures. For this reason, the Millet order applied by the Ottoman Empire is a "sui generis" (unique in its kind) event in history. ${ }^{19}$

The Millet System had a direct impact on Albanian nationalism as well. In the Millet System, the separation of societies according to religious and sectarian groups rather than ethnicity affected some nations positively and some nations negatively. In this system, it is observed that the Orthodox believers were organised under the category of the Greek Orthodox and continued their existence in integrity. Greeks and Slavs, thanks to the usage of Greek and Slavic languages in religious ceremonies and in all Orthodox entities, have managed to protect the basic parts of their culture with the most important tool, the language.

On the other hand, Albanians, who were Muslims, Catholics and Orthodox, have been divided due to the system. The Millet System impacted the Albanian nationalism in terms of its development and its course of action. Thus under this context it separated the Albanian nationalism from other Balkan nationalisms. Consequently, this led to the differentation between Albanians, who were already experiencing social division. It is seen that the Albanians who were Orthodox believers came under Hellenic influence and they were called "Arvanid" by the Ottoman Empire. ${ }^{20}$ On the other hand, Catholic Albanians seem to have been influenced by the Renaissance in Italy and have called their own clan "Arbëresh". It is noted that the Albanians who are Muslim are defined as Turkish by Westerners and the term "Turco-Albanian"21 is used by the Greeks to define Muslim Albanians. ${ }^{22}$ Even among the Muslim Albanians, who adopted the Sunni and Bektashi sects, there were many differences of opinion.

In the post-Tanzimat era, the regional Balkan countries gathered on an ethnic axis structure. This was an alliance between different lands and people based on their language, alphabet, education and national consciousness. Considering the ethnic axis structure formed in the region and compared to their neighbours, Albanians were left behind in terms of language, alphabet, education and national consciousness thus they were late in establishing their nation-state. On the other hand, in the region,

19 Ortayli 2015.

20 CAKA 2015, 17-21.

21 From 1715 onwards, it was observed that they were called in this way. "Тоирк $\alpha \lambda \beta \alpha v o$ o" (Tourkalvanoi). For details: Millas 2009, 47-60. 
thanks to the support of the foreign powers, and especially Russia, states such as Greece, Serbia, Bulgaria, and Romania emerged and gained their independence.

On the other hand, the Albanians, the majority of whom are Muslim, have not received the support of the great powers in the same level as the other Balkan peoples. Albanians suffered many injustices due to the power rivalry between Italy and AustriaHungary in the Western Balkans. ${ }^{23}$ At the London Conference in 1913, while defining the borders, two-thirds of the lands where Albanians lived and more than half of the Albanian population remained outside the borders of the newly established Albanian state. $^{24}$

\section{Devshirmeh System}

With the intention of enhancing and consolidating its power, the Ottoman Empire needed to expand the borders. On the other hand, while the Ottoman Empire conquered new territories and expanded its borders, it used the "Devshirmeh System" 25 in order to meet the administrative and military personnel needs. Such a system has been used to create a high level of military and governance, especially by recruiting young and talented children from the Christian communities in Rumelia and subjecting them to a rigorous education. As in the Ottoman Empire, there have been examples of the upbringing of foreign youth (8-18 years old) in Roman, Byzantine, and many Islamic states. In the conquered lands, one-fifth of the Christian children were taken, circumcised and educated at the "Enderun Mektebi" ${ }^{26}$ school with Turkish-Islamic upbringing and military training.

As specified by the Devshirmeh System, the children were collected considering many qualities. In this regard, the Christian nobles' children, the priests' sons, the healthiest son of the families with more than one child were taken, but this didn't happen to the families with only one son. Children without parents were not selected since they did not receive family discipline. The system did not prefer to recruit neither the children known to be city-dweller and greedy, nor the bald, egoistic, beardless, blond, very tall and very short children and the boys who were circumcised in a young age. In addition, "Devshirmeh" was not made from all nationalities. Generally Albanian, Bosniak, Bulgarian, Greek, Serbian and Croatian children were selected, while Turkish, Kurdish, Persian, Russian, Georgian, Jewish and Gypsy children were not recruited. Armenians were rarely recruited for palace affairs. ${ }^{27}$

The recruitment was initially made in Rumelia from the zones where Albanians mostly lived; in places such as Skopje, Shtip, Prizren, Gjirokastra, Ioannina, Shkodra,

23 FISCHER 2014, 37.

24 CAKA 2015, 20.

25 The process of recruiting Christians and bringing them up to be part of the Janissaries troops.

26 Special school in the Ottoman Palace.

27 İLGÜREL 1986, 385. 
Ohrid, Peja, Dukagjin and Manastir (Bitola). ${ }^{28}$ With the Devshirme System, Veli Mahmud Pasha, Rum Mehmed Pasha, Yunus Pasha, Rüstem Pasha, Kuyucu Murad Pasha, and Pargalı İbrahim Pasha were the ones who rose to the Grand Vizier. However, there are also examples considered negative for the system such as İskender Bey (Skanderbeg). ${ }^{29}$

During the reign of Murad II, even though Skanderbeg initially carried out successful military services, he did not break ties with Albania and captured the Kruja $^{30}$ (Akçahisar) Castle with a false decree he had prepared and then made resistance against the Ottoman Empire. ${ }^{31}$ Skanderbeg, who rejected Islam and declared that he rebelled against the Ottoman Empire to avenge his family, received all kinds of financial and military assistance from the Kingdom of Naples and the Vatican. Skanderbeg, having had a good military training in the same period when Sultan Mehmed the Conqueror also had his military training, was successful in the battles against the Ottoman Empire, thanks to the information he had and due to the fact that the siege of Kruja Castle was not possible because of its geographical conditions. ${ }^{32}$ This uprising, in an actual perception, is incompatible with Albanian nationalism, and as Hans Kohn points out, the fact that nations need historical myths to consolidate their existence gains importance within this context. ${ }^{33}$ For this reason, this historical myth was necessary to awake Albanian nationalism in the 19th century while Enver Hoxha used it to consolidate national consciousness in the 20th century. However, the attention was not focused on how accurate and how objective from the historical point of view these myths were, the most important matter was the fact that these myths were able to convince and thus mobilise the masses.

\section{Socio-Economic Structure of the Ottoman Empire}

It is seen that the socio-economic structure of the Ottoman Empire was founded on various systems and taxes in the center of the rural economy. In the social community, just like the tax liability obligation for the reâyâ class, the head tax (haracı) is collected - based on Islamic law ${ }^{34}$ - from non-Muslims under the name of "jizya". Jizya obligation is charged by the landowners who are called "baştina". ${ }^{35}$ Likewise, this

28 ÖzCAN 1994, 254.

29 Albanian: Gjergj Kastrioti Skënderbeu.

30 Albanian: Krujë.

31 UZunCARŞıLI 2011, 209.

32 Rrapaj-Kolasi 2013, 223.

33 Kuzio 2002, 32-33.

34 The Ottoman Empire collected the Jizya Tax from non-Muslims according to the 29th Ayat of Surat at-Tawbah in the Quran. Surat-at-Tawbah 29th: "Fight those who do not believe in Allah or in the Last Day and who do not consider unlawful what Allah and His Messenger have made unlawful and who do not adopt the religion of truth from those who were given the Scripture - [fight] until they give the jizyah willingly while they are humbled." For more information see: http://islamicstudies. info/reference.php?sura $=9$ \&verse $=29(10.10 .2019)$

İNALCIK 2011, 57. 
tax was taken under the name of "capitatio", "kephaletikon", "gezit" from believers of different faith in Roman, Byzantine, or Sassanid Empires.

Jizya, in accordance with the principles of Islamic law, is taken from the nonMuslims as paid for the military service obligation. Although this term was abolished after the Tanzimat Edict of 1839, the tax continued to be collected from non-Muslims under the name of the bedel-i askeri ${ }^{36}$ (paid military obligation). ${ }^{37}$

The positive influence of Sari Saltik services in the region before the Ottoman period, as well as the tolerance and protection (istimâlet) policy followed in the Balkans in the Ottoman period, the resettlement (iskan) ${ }^{38}$ and Jizya policies, were all influential in the decision of Albanians, Bosnians, Torbesh and Pomaks toward accepting Islam. Regardless the fact that the convertion of the majority of Albanians to Islam had a positive effect on the increase of their influence on the Ottoman administration, the truth is that compared to other Balkan communities Albanians being divided in terms of faith affected negatively Albanian nationalism. The influence of Jizya on Albanian nationalism brought changes at the structural level and directly shaped the methodology of Albanian nationalism.

Subject to a traditional agricultural economy, the "Çift-Hane System" of the Ottoman Empire is the only significant factor in the understanding of the rural economic structure in Anatolia and Rumelia during the classical period of the Empire between 1300 and 1600 . The wealth of the empire was based on agricultural land ownership and agricultural production. The opening of the land to agriculture, cultivation, irrigation, harvesting are dependent on human and animal power. Besides the procurement and adoption of the means of production, the process of transporting the product to the markets emerges as business segments necessitating cost and administration. For this type of organisation, the economic and social aspects of the management and execution of the necessary legal measures for the implementation of this large agricultural organisation is provided by the "Çift-Hane System". ${ }^{39}$ The concepts of small peasants, family farms like the "Jugum Caput" in the late Roman Empire," Zeugarion" in the Byzantine Empire did not differ from the "ÇiftHane System" in the Ottoman Empire. ${ }^{40}$

The "Çift-Hane System" is reciprocal and interdependent with some other systems of the empire. The Ottoman "Timar-Sipahi System" depends on the functioning of the "Çift-Hane System". Therefore, the Çift-Hane System, Timar (Dirlik) System and the Çift-Hane unit is intertwined as Miri-Tapulu land system. ${ }^{41}$ It is seen that the Timar

36 There are also examples of non-Muslim soldiers who did not pay this price and served the Ottoman Empire in the army and navy, as well as some Muslim youth who were exempted from the army by paying this military service price (bedeli).

37 Ortayli 2015, 1.

38 In order to make Turkish and Islamise the territories that the Ottoman Empire conquered, the policy of settling Turkmen tribes in the newly conquered regions is called as "iskan" policy.

39 Orbay 2011, 1.

40 İNALCIK 2011, 16.

41 İNALCIK 1994, 145-146. 
System goes back to the period of Orhan Bey in terms of documents. The meaning of the Timar System, is care and attention. Through this particular care and attention, the system provided the sustainability of the military-administrative hierarchy in the Ottoman central provinces. Furthermore, the Timar System was not only the basis of the military-administrative organization of the empire, but was also a determining factor in the functioning of the "Miri" land system, in determining the status of the peasant-farmers and the tax payable, and in the management of the agricultural economy in the classical age of the Ottoman Empire. ${ }^{42}$

In addition to all these, the guild organisation system established by the artisans and craftsmen living in the same region, stands out as another factor preventing the birth of the bourgeoisie class in the Ottoman Empire. Due to the absence of the bourgeoisie class and the tax-based classical rural economic system imposed by the Ottoman Empire, the Balkans remained outside ${ }^{43}$ world economy established since 1492. ${ }^{44}$ For this reason, historians and nationalists from Albania as well as from other Balkan countries, ${ }^{45}$ attribute the grounds of the Balkans backwardness as a result of the economic system implemented by the Ottoman Empire. Although many of the systems used by the Ottoman Empire were similar to those of the early empires in the region, or systems created with soft transition formulas, many theses adopted by Albanian historians claim that the production system, social structures and economic strength of the Albanian communities in the pre-Ottoman region were at a more advanced level. ${ }^{46}$

According to Ernest Gellner, nationalism is the product of the industrial social organisation. ${ }^{47}$ According to the modernist nationalist approach, nationalism has become a sociological necessity only in the modern world. Gellner categorized human life into three stages: the hunter-gatherer, the agro-literate, and the industrial one. The Albanians, which are under the domination of the Ottoman Empire, are placed in the second stage the agro-literate stage. The ruling class uses its culture to separate itself directly from the vast majority of agricultural producers. For this reason, considering that there is no cultural homogenisation in agricultural societies, no convenient environment can be formed to establish a nation-state. In the third stage, factors such as capitalism, industrialisation, urbanisation, secularisation and modern bureaucracy, which were formed along with modern developments in the last two centuries, led to the formation of the concepts of nation and nationalism. ${ }^{48}$ However, the system of governance implemented by the Ottoman Empire led Albanian nationalism to reach the third stage much later than the nationalist movement in Europe.

42 İNALCIK 2011, 117.

43 Wallerstein 1979, 390.

44 The history of the North American expedition, led by Christopher Columbus across the Atlantic Ocean in 1492, is considered a symbolic date of the establishment of the world economy.

45 Rrapaj-Kolasi 2013, 193-194.

46 Rrapaj-Kolasi 2013, 193-194.

47 GeLlNer 1983, 25.

48 ÖZKırıMLı 2017, 70-71. 


\section{Administrative Structure of the Ottoman Empire}

The administrative system of the Ottoman Empire was divided into rural administrative units, in other words, provinces (vilayet), which were governed by the "beylerbeyi" and were formed with the unification of villages and sanjaks. After 1591, the Arabic word "eyalet", meaning governing and executing, was adopted. ${ }^{49}$ Due to political, economic and physical distance and conditions, the provinces were divided into three sections: Salyaneli ${ }^{50}$ (Annually), Salyanesiz (Non-annually) and İmtiyazll ${ }^{51}$ (Privileged).

Regions like Anatolia, Diyarbakır, Erzurum, Damascus, and Van, including Rumelia, where the Balkans is located, have been identified as Salyanesiz (Nonannually) provinces. The Salyanesiz provinces, which form the center of the Ottoman Empire, are naturally the most influenced regions in terms of administrative, economic, religious and social areas. After the Tanzimat Period, through changes made to the border and administrative units in the provinces within the "Vilayet Regulations" (Vilayet Nizamnamesi) issued by the Ottoman Empire in 1864, it was passed to the "Vilayet System". ${ }^{2}$

With the transition to the Vilayet System, the regions where the majority of Albanians live were divided into four different provinces: Kosovo, Shkodra, Monastery and Ioannina. Albanians being divided with regard to religion and sects, their administrative and geographical division was also inevitable. This division affected negatively Albanian nationalism. Due to many physical and geographical barriers in the region where Albanians live, they experienced difficulties in communicating among themselves. The lack of a good communication and interaction required by the nationalist movement had a negative impact on the emergence of the movement. On the other hand, the borders of the provinces drawn by the Ottoman Empire formed the boundaries of the "Greater Albania Idea" which was the only aim of the Albanians. Considering the actual borders of the Balkan states, the "Greater Albania

49 İNALCIK 2011, 73.

50 Salyaneli (Annual) Provinces is the name given to the administration of provinces far from the center such as Egypt, Tunisia, Tripoli, Abyssinia, Yemen. The Timar System is not implemented on them. After paying the salary of the tax collector, the rest is transferred annually to the coffers of the Ottoman Empire.

51 İmtiyazlı (Privileged) Provinces is used for the provinces which are far from the center and free in their internal affair (the provinces of Wallachia, Moldova, and Transilvania), still, they have military and tax obligations. The Crimean State is exempt from tax and tax obligations. The Hejaz State, which houses the holy lands, is exempt from tax and tax obligations.

52 Kartal 2014, 1. 
Idea" ${ }^{53}$ refers to the area that covers the whole of Albania and Kosovo, the southwest of Serbia, the south of Montenegro, the west and northwest of Northern Macedonia, and the northwest of Greece.

\section{Conclusion}

The Balkans was seen by the Ottoman Empire not only as an imperial land, but also as a homeland. Therefore, there have been mutual interaction in political, economic, cultural, religious, social life and in many other different aspects and spheres of life. As it happened with all Balkan nationalisms, the rule of the Ottoman Empire was the factor shaping Albanian nationalism as well. It also developed on the basis of the conditions determined by the Ottoman Empire in the region.

Under the influence of the governing system, the Albanians' nationalist movement was the latest developing nationalist movement in the Balkans, as well as the most differently evolving movement compared to other Balkan nationalisms. This was one of the most remarkable events in the 19th century's Balkan history. Many arguments developed in Albanian nationalism have been about the Ottoman Empire. As with other nationalisms in the Balkans, in order to strengthen its own nationalism, it built the perception of the common enemy and the "other" to break ties with the Ottoman Empire, since it expressed its relations with the old governance.

These arguments were not used by many historians and nationalists because they were accurate or true, but because they were considered necessary. For them it is of greater importance that the claims were convincing and could "mobilize the masses", and of less importance whether they were based on facts. In most of the Balkan historiography, the perception about the Ottomans is negative. On the other hand, the perception of the Bosnian historians, who are partners in terms of faith, is positive. Even though a minority, there are Romanian and Albanian historians that have a positive perception towards the Ottoman Empire because it prevented the destruction of the existence and culture of their nations from the Slavic invasion and assimilation, thus they saw the Empire as a protector.

53 For this idea such notions are used: "Greater Albania” (Alb.: Shqipëria e Madhe, Tr.: Büyük Arnavutluk), "Ethnic Albania" (Alb.: Shqipëria Etnike, Tr.: Etnik Arnavutluk) and "Natural Albania" (Alb.: Shqipëria Natyrale, Tr.: Doğal Arnavutluk). In addition, Albanians use the discourse of "Reunification of the Albanian Nation" (Alb.: Ribashkimi Kombëtar Shqiptar, Tr.: Arnavut Milletinin Tekrardan Birleşmesi). For more information to see: JUDAH 2008, 120. The book can be reached from the following link: https://books.google.com/books?id=WjTRCwAAQBAJ\&pg=$\mathrm{PA} 120 \& \mathrm{dq}=$ Albanian + nationalists\& $\mathrm{hl}=\mathrm{en} \& \mathrm{sa}=\mathrm{X} \&$ redir_esc $=\mathrm{y} \# \mathrm{v}=$ onepage $\& \mathrm{q}=$ Albanian\%20nationalists\&f=false (12.10.2019) 


\section{Bibliography}

\section{Print literature}

Aкşın, Sina (2007): Turkey From the Empire to Revolutionary Republic: The Emergence of the Turkish Nation from 1789 to the Present. New York, New York University Press.

CAKA, Eduart (2015): Millet Sisteminde Arnavutların Durumu, Osmanlı Millet Sisteminde Arnavutların Konumu (XVII-XIX. Asırlar). Journal of Balkan Studies, Vol. 6, No. 1. 7-22.

Gellner, Ernest (1983): Nations and Nationalism. 1. Edition. New York, Cornell University Press. Göyünç, Nejat (2001): Pax Ottomana. In Kemal Çiçek ed.: Studies In Memoriam Prof. Dr. Nejat Göyünç. Ankara, Yeni Türkiye Publications. 31-49.

İLGÜREL, Mücteba (1986): Yeniçeriler, İA, Vol. 13, İstanbul. 388.

İNALCIK, Halil (1994): State, Land and Peasent: The Çift-hane System: the Organization of Ottoman

Rural Society, In Halil İNALCiK and Donald Quataert eds: An Economic and Social History of the Ottoman Empire 1300-1914. New York, Press Syndicate of the University of Cambridge.

İNALCIK, Halil (2011): Eyalet İdaresi: Cizye ve Gayrimüslimler, In id.: Osmanlı İdare ve Ekonomik Tarihi. Istanbul, İSAM Publications.

Judah, Tim (2008). Kosovo: Whats Everyone Needs to Know? New York, Oxford University Press. KalL1op1, Nikolopoulou (2013). Tragically Speaking: On the Use and Abuse of Theory for Life.

Nebraska, Nebraska University Press. DOI: https://doi.org/10.2307/j.ctt1ddr6jt

Millas, Iraklis (2009): Tourkokratia: History and the Image of Turks in Greek Literature.

South European Society and Politics, Vol. 11, No. 1. 47-60. DOI: https://doi.org/10.1080/ 13608740500470315

Özcan, Abdülkadir (1994): Devşirme. İSAM, c. 9, Istanbul.

ÖzKırıMLl, Umut (2017): 'Chapter 3: Primordialism/Perennialism. In id. ed.: Theories of Nationalism: A Critical Introduction. London, Palgrave. 51-80.

RrapaJ, Jonilda - Kolasi, Klevis (2013): The Curious Case of Albanian Nationalism: the Crooked

Line from a Scattered Array of Clans to a Nation-State. The Turkish Year Book of International Relations, Vol. 44, 185-228. DOI: https://doi.org/10.1501/intrel_0000000290

Todorova, Maria (2010). Balkanları Tahayyül Etmek, Translated by Dilek Şendil, ed. Tansel Güney, 3. ed. Istanbul, İletişim Publication.

UZUNÇARşıLı, İsmail Hakkı (2011). Osmanlı Tarihi. Ankara, TTK Publication, 10. B, Vol.1.

Wallerstein, Immanuel (1979). The Ottoman Empire and the Capitalist World-Economy: Some

Questions for Research, Review (Fernand Bruadel Center), Vol. 2, No. 3.

\section{Online Resources}

EsER, Ümit (2010): Milletlerin Varlığı ve Özerkliği Hakkındaki Tartışmalar, Millet Sisteminin Tarihi Arka Planı: Gayrimüslim Cemaatler İçin Özerk Bir Alan. Balıkesir University Journal of Institute of Social Sciences, Vol. 13, No. 24. Available: http://sbe.balikesir.edu.tr/dergi/edergi/c13s24/ makale/c13s24mk.pdf (06. 10. 2019)

Fischer, Bernd (2014): Albanian Nationalism and Albanian Independence, De Gruyter Open, Seeu Review, Vol. 10, No. 1, 25-38. DOI: https://doi.org/10.2478/seeur-2014-0005

İNALCıK, Halil (2015): Osmanlı Fütuhatının Sonuçları, Türkler ve Balkanlar, Available: www.inalcik. com/images/pdfs/15810373TURKLERVEBALKANLAR.pdf (05. 10. 2019) 
Kartal, Nazım (2014): İl Sistemine Geçiş Sorunsalı: Türkiye'de 1864 Vilayet Nizamnamesi ile İl Sistemine Geçilmiş midir? Journal of International Management, Economics and Business, Vol. 10, No. 23. DOI: https://doi.org/10.17130/ijmeb.2014.10.23.611

Konan, Belkıs (2011): İnsan Hakları Ve Temel Özgürlükler Açısından Osmanlı Devletine Bakış. Gazi University Journal of the Faculty of Law, Vol. 15, No. 4, 253-288. Available: https:// dergipark.org.tr/en/download/article-file/789420 (08. 10. 2019)

Kuzio, Taras (2002): The Myth of The Civic State: A Critical Survey of Hans Kohn's Framework for Understanding Nationalism. Ethnic and Racial Studies, Vol. 25, No. 1. 20-39. DOI: https://doi. org/10.1080/01419870120112049

Orbay, Kayhan (2011): Osmanlı Çift-hane Sistemi, Ankara University Institute of Social Sciences Department of Economics, (Unpublished Master's Thesis). Available: www.academia. edu/27999598/Osmanl\%C4\%B1_\%C3\%A7ift-hane_sistemi (11.10. 2019)

Ortayll, İlber (2015): Osmanl İmparatorluğu’nda Millet Sistemi. Available: www.tarihtarih. com/?Syf=26\&Syz=381989 (08. 10. 2019)

"Ahl al-Kitāb", Encyclopæedia Britannica (2019). Available: www.britannica.com/topic/Ahl-al-Kitab (07. 10. 2019)

“Millet Nedir?", Yüce Devlet.com (13 January 2012). Available: www.yucedevlet.com/millet-nedir. html (07. 10. 2019)

"Reaya sınıfına genel bir bakış", Tarih Haber (2015). Available: www.tarihhaber.net/reaya-sinifinagenel-bir-bakis/ (06. 10. 2019)

"Spahi", Collins (2019). Available: www.collinsdictionary.com/dictionary/english/spahi (06. 10. 2019).

"Surah At-Tawbah 29th Ayat Tafsir", Tafheem ul Quran (2019). Available: http://islamicstudies.info/ reference.php? sura $=9 \&$ verse $=29$ (10.10. 2019)

“Zimmî”, Türk Diyanet Vakfı İslam Ansiklopedisi (2019). Available: https://islamansiklopedisi.org. tr/zimmi (08. 10. 2019) 